\title{
The Effect of The Role of The Internal Control System on Good University Governance In Private Education In Medan
}

\author{
Zulia Hanum ${ }^{1}$, Iskandar Muda ${ }^{2}$, Rina Bukit ${ }^{3}$ Muhyarsyah $^{4}$ \\ \{iskandarl@usu.ac.id\} \\ Faculty of Economics and Businees, Universitas Sumatera Utara, Medan, Indonesia ${ }^{1,2,3,4}$
}

\begin{abstract}
This study aims to determine the effect of the role of the internal control system on Good University Governance in Private Colleges. This research was conducted because there are still indications related to performance in the city of Medan. This study used a sample study program at the Medan City Private University in the form of an office and a body of 200 samples. This research uses Smart PLS software. The results showed that the role of the internal control system has been implemented very well. In addition, the implementation of internal control systems is also in accordance with the principles of good governance. The results also showed that there was a positive influence between the role of the internal control system on Good University Governance. So H0 is rejected and Ha is accepted. Keywords: Internal Control System, Good Governance.
\end{abstract}

Keyword : University, Education.

\section{Introduction}

Education is a very important thing that must be felt by every human being. Higher education is one of the institutions that play a role in educational practice. Higher education institutions have a privilege compared to other institutions lies in their basic functions, namely in terms of education, teaching and business discovery or innovation (research). These functions then define the role of higher education in society. The discourse which then often surfaced in the organization of tertiary institutions was then about academic excellence and management of tertiary institutions, including in terms of financing. Higher education institutions have a privilege compared to other institutions lies in their basic functions, namely in terms of education, teaching and business discovery or innovation (research). These functions then define the role of higher education in society. The discourse which then often surfaced in the organization of tertiary institutions was then about academic excellence and management of tertiary institutions, including in terms of financing. The answer from these two discourses then depends on how a country's understanding in applying good university governance (Sukirman and Sari, 2012). Good University Governance (GUG) is a concept that is currently being mainstreamed in the administration of higher education. This concept is a derivative of the concept of good governance. The purpose of this concept is to create an accountable university. The initial effort of the government in the framework of implementing the concept of good university governance (GUG) is to form a work unit that applies the financial governance pattern of public service bodies. Public Service Agency colleges are 
required to apply the principles of good governance. One of the principles of good governance is transparency and accountability. Accountability and transparency are intended to ensure that the management of government finances carried out by the government apparatus runs well. Until now, the issue of transparency and accountability of organizations, especially in the colleges of the Public Service Agency (BLU), has still not changed significantly. The phenomenon of fraud behavior in state universities has actually surfaced in recent years. Based on Indonesian Corruption Watch (ICW) data, it is stated that in the span of 10 years from the beginning of 2006 to August 2016 there were 37 cases of corruption involving tertiary institutions (Yuntho, in Ahmad Faisal Anshori (2017). Based on ICW's observation there were 12 patterns of corruption in tertiary institutions and the most is corruption in the field of procurement of goods and services. Other patterns include misappropriation of grants and Corporate Social Responsibility (CSR), internal budget corruption, corruption in sales of higher education assets and corruption of Student Education Development Donations (SPP) funds (Yuntho, in Ahmad Faisal Anshori (2017) The following are a number of cases of fraud or corruption that occurred in tertiary institutions as follows: The case of the construction of UNAIR teaching hospital with a loss of Rp 85 billion, then cases of corruption in the process of budgeting, procurement of goods and services Information technology infrastructure installation project Library building P usat University of Indonesia in 2010-2011 with a total loss of Rp. 13,076 billion.

Based on the background that has been stated, the problem formulation in this study is whether the Internal Control System (SPI) has a positive effect on the implementation of good university governance in Private Universities.

The purpose of this study is to reexamine and obtain empirical evidence whether the Internal Oversight Unit (SPI) and internal control have an effect on good university governance in Private Universities.

Stewardship Theory Stewardship theory has psychological and sociological roots that are designed to explain situations where managers are stewards and act in the interests of the owner (Donaldson \& Davis, 1991 in Fadli). Stewardship theory explains that managers will behave according to common interests. When the interests of the steward and the owner are not the same, the steward will try to work together rather than against it, because the steward feels the common interests and behaves.

Internal Control System

According to Arens (2008: 258) internal control is as follows: "Internal control is policies and procedures designed to provide management with sufficient confidence that the goals and objectives that are important for business units can be achieved and together form a control structure. internal business "

The Committee of Sponsoring Organizations of the Treadway Commission (COSO) issued the Internal Control Integrated Framework (ICIF). The definition of internal control according to COSO (2013: 3) is as follows: "The internal control system is a process that involves the board of commissioners, management, and other personnel, which is designed to provide reasonable confidence in achieving the following three objectives: Effectiveness and efficiency of operations, reliability of financial reporting, compliance with applicable laws and regulations "

Good University Governance according to Wijatno (2009: 126) can be seen as the application of the basic principles of the concept of "good governance" in the system and process of governance in tertiary institutions through various adjustments made based on values that must be upheld in the administration of higher education specifically and education generally. according to Dikti there are 8 principles of good university governance that must be 
applied by universities in Indonesia, the eight principles are: 1) Transparency, 2) Accountability (to stakeholders), 3) Responsibility, 4) Independence (in making decisions), 5) Fair,

\section{Research Methods}

Type of Research The research approach used is a quantitative approach. This research is presented with numbers in order to test or verify the theory, examine the relationships between variables, determine the causality of the variables, and look for generalizations that have predictive value (to predict a phenomenon). This approach is used to obtain objective, valid, and reliable data by using data that is formed in numbers or qualitative data that is measured (Sugiyono, 2002). The population in this study were all private universities in the city of Medan, a sample of 200 The type of data in this study is primary data obtained directly from the source through the distribution of questionnaires distributed to the Chair of the Study Program

The questionnaire distributed uses a Likert scale to make it easier for respondents to understand the scoring from highest to lowest. There are 5 rating scales, namely:

a. Strongly disagree, given a weight of 1

b. Disagree, given a weight of 2

c. Enough, given a weight of 3

d. Agree, given a weight of 4

e. Strongly Agree, given a weight of 5

Analysis of the data used to answer hypothesis testing using descriptive statistics and Smart PLS

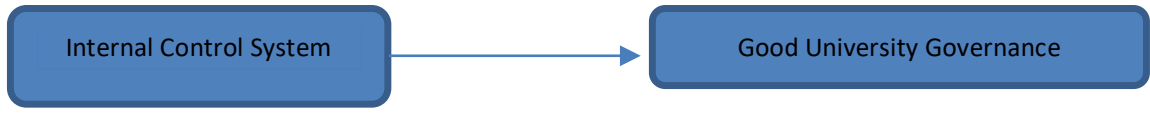

Fig.1. Hypothesis testing using descriptive statistics and Smart PLS

\section{Result and Discussion}

Test of Significance of Direct Effect (Dirrect Effect), The table below presents the path coefficient results and the test of the significance of direct effects. efficient values and Pvalues (Testing the Significance of Direct Effects) Variable Part Coefficien P-Value Decision Criteria.

Table 1. Test of Significance of Direct Effect (Dirrect Effect)

\begin{tabular}{ccccc}
\hline Variabel & Part Coefficien & P-Value & Kriteria & Decision \\
\hline SPI-)GUG & 0.812 & 0.000 & 0.05 & Received
\end{tabular}

Based on the table above, the Internal Control Unit (SPI) Variable has a positive effect on Good University Governance (GUG) with a path coefficient of 0.669 and is significant with a P-Value of $0,000<0.05$. The results of this study are in line with research conducted by Puspitarini et al (2013), Sukirman et al (2012), and Kholiyah et al (2017). This is also in 
accordance with the explanation of Mardiasmo (2009) stating that, there are three main aspects that support the creation of good governance, namely supervision, control, and inspection and these three aspects can be implemented by internal auditors.

\section{Conclusion}

Based on the results of research and theoretical studies that have been stated previously, the writer can conclude that the role of the internal control system (SPI) has a positive and significant effect on the achievement of good university governance (GUG). research conducted by Puspitarini et al (2013), Sukirman et al (2012), and Kholiyah et al (2017). This is also in accordance with the explanation of Mardiasmo (2009) stating that, there are three main aspects that support the creation of good governance, namely supervision, control, and inspection and these three aspects can be implemented by internal auditors.

\section{References}

[1] Ansori Ahmad Faisol, 2017, Pengaruh Implementasi Good University Governance,Keefektifan Sistem Pengendalian Internal Dan Ketaatan Aturan Akuntansi Terhadap Kecenderungan Fraud Pada Ptkin-Blu, Univversitas Lampung Bandar Lampung.

[2] Arens, A. A., Elder, R. J., \& Beasley, M. S. 2008. Auditing dan Jasa Assurance Jilid 1. Jakarta: Erlangga.

[3] Arikunto, Suharsimi. 2006. Prosedur Penelitian: Suatu Pendekatan Penelitian. Jakarta: Rineka Cipta.

[4] Fadli Achmad, 2017. Pengaruh Peran Satuan Pengawasan Internal Terhadap Pencapaian Good University Governance Dengan Penerapan Pengendalian Internal Sebagai Variabel Intervening.

[5] Ghozali, Iman, 2011, Aplikasi Analisis Multivariate Dengan Program IBM SPSS 19 (edisi kelima), Semarang.

[6] Kartika, Ratu Rika. 2010. Pengaruh Motivasi Kerja dan Pengendalian Internal Terhadap Kinerja Berbasis Good Governance pada Pemerintah Provinsi Banten. Skripsi. Bandung: Fakultas Ekonomi Universitas Padjadjaran. Mardiasmo. 2002. Akuntansi Sektor Publik. Yogyakarta: ANDI.

[7] Mardiasmo. 2009. AkuntansiSektorPublik. Edisi Revisi 2009. Penerbit Andi Penerbit Andi Yogyakarta: Peraturan BPK tahun 2017 nomor 1, Tentang Standar Pemeriksaan Keuangan Negara. Jakarta Peraturan Menteri Agama Republik Indonesia Nomor 25 Tahun 2017 tentang Satuan Pengawasan Internal Pada Perguruan Tinggi Keagamaan Negeri, Jakarta

[8] Mulyadi, Johny Setiawan. 1999. Sistem Perencanaan dan Pengendalian Manajemen: Sistem Pelipatgandaan Kinerja Perusahaan. Yogyakarta:

[9] Sukarmaji, Sanni Kemal Razali. 2011. Pengaruh Pengendalian Internal Terhadap Kinerja Berbasis Good Governance Pada Pemerintah Kota Sukabumi. Skripsi. Bandung: Fakultas Ekonomi Universitas Padjadjaran.

[10] Sukmana, Wawan., Lia Anggarsari. 2009. Pengaruh Pengawasan Intern Dan Pelaksanaan Sistem Akuntansi Keuangan Daerah Terhadap Kinerja Pemerintah Daerah (Survey Pada Satuan Kerja Perangkat Dinas Daerah Kota Tasikmalaya). Jurnal Akuntansi Fakultas Ekonomi Universitas Siliwangi, vol. 4, no. 1, 2009.

[11] Sukirman, dan Sari. 2012. Peran Internal Audit Dalam Upaya Mewujudkan Good University Governance Di Unnes. Jurnal Dinamika Akuntansi (JDA). Vol. 4 No 1. 4:8

[12] Tresnawati, Rina. 2012. Pengaruh Efektivitas Pengendalian Intern terhadap Kinerja

[13] Wijatno, Serian. Pengelolaan Perguruan Tinggi Secara Efisien, Efektif, dan Ekonomis untuk Meningkatkan Penyelenggaraan Pendidikan dan Mutu Lulusan. Salemba Empat. Jakarta. 2009. 
